\title{
RECENZE
}

\section{STYLISTKA PRVNÍ DÁMY}

\author{
Miroslava Burianová
}

Maria SzAdKowsKa (ed.), Božena Rothmayerová Horneková a Alice Masaryková.

Svěrenkyně a mentor (1926-1939), Muzeum hlavního města Prahy, Praha 2019, 316 s., ISBN 978-80-87828-45-8.

Božena Horneková by zřejmě zůstala pro většinu i odborné veřejnosti neznámou ženou, kdyby ke svému jménu v roce 1928 nepřipojila jméno architekta Otto Rothmayera. Pravdou je, že bez Rothmayera by s Alicí Masarykovou nezačala spolupracovat a nemohla by tak pro ni mimo jiné vytvořit garderobu společensky angažované ženy.

Božena je přitom spojena minimálně se třemi mimořádnými momenty dějin odívání: v závěru 20. let jako tvưrkyně kalhotového šatníku pro moderní ženu; jako designérka nadčasových prostírání a drhaných šperků, tj. krajkářka; a jako zakladatelka nového oboru restaurování a konzervování textilií v Ústavu pro domácký průmysl v Praze, kde léta pedagogicky působila.

Podnětem k výzkumu v písemnostech manželů Boženy a Otty Rothmayerových se stalo převzetí jejich vily v pražských Střešovicích do správy Muzea hlavního města Prahy. Druhým motivem byla výstava v prostoru Studijního a dokumentačního centra památek moderní architektury v Praze na Norbertově, tj. shodou okolností nedaleko zmíněné vily. Stalo se tak na přelomu let 2018/2019. Jak autorka v prologu uvádí, kniha vyšla jako doprovodná publikace k této výstavě. Omezovat její účel na pouhý doplněk výstavy ale považuji za příliš skromné. Výstava, ač zajímavá - prezentovala repliky šatníku pro moderní ženu, který Božena navrhla pro výstavu Civilisovaná žena v Brně v roce 1929, ostatně fotografie těchto replik mají své místo i v publikaci - má pomíjivou hodnotu. Naopak kniha, která není jen edicí (její součástí je obsáhlá studie a bohatý obrazový materiál), je trvalým prínosem pro všechny, kdo by chtěli této zajímavé ženě věnovat svoji pozornost.

Autorka začíná sledovat Boženin život na základní škole v pražské Šárce. Další studium absolvovala Božena na holešovickém lyceu, které musela pro špatný prospěch opustit, a pokračovala na Uměleckoprůmyslové škole v Praze.
Nejprve vystudovala obor figurální a ornamentální modelování a ciselérství. Po dokončení studia absolvovala ještě obor Speciální škola pro umělé vyšívání. To ji předurčilo k celoživotní práci textilní výtvarnice.

Ottu Rothmayera mohla Božena poznat během studia na Uměleckoprůmyslové škole, ale mohli se znát i mnohem déle, nebot' Otta byl př́telem Boženina bratra Jana. Zasnoubili se $\mathrm{v}$ roce 1921 a v následujícím roce Božena začala učit ve škole pro ženská povolání Světlá ve Velkém Meziříčí. K obnovení kontakti̊ Boženy s Alicí Masarykovou došlo v souvislosti s působením Rothmayera jako architekta při přestavbě Pražského hradu.

Škoda, že asi nelze dohledat význam prvního dárku, který Alice Boženě poslala k Vánocům roku 1925. Byl to malý šáteček, možná spíše kapesník, a Alice k němu napsala: „Je starý a má významnou historii..." Ač je to neuvěřitelné, $\mathrm{v}$ pozůstalosti se dochoval. $\mathrm{V}$ popisce $\mathrm{k}$ fotografii bohužel není uveden ani rozměr, materiál ani popis techniky. Podle fotografie lze hádat, že jeho hodnota pro Alici nebyla dána stárím, ale spíše osobním prožitkem s ním spojeným. Škoda, že tento př́iběh se asi již nikdy nedozvíme.

Zmíněným malým dárkem začala korespondence mezi bývalou pedagožkou a její žákyní. Alice se v ní snažila ovlivnit Boženino směřování, zadávala jí úkoly. Ty se týkaly jak její osobní garderoby, tak vybavení rekonstruovaných prostor Pražského hradu, především zřejmě Dámského salonu.

Další osobou, která velmi silně ovlivnila Boženino estetické cítění a tím i profesní život, byl architekt Jan Vaněk. Seznámili se v době, kdy Božena učila na škole uměleckých řemesel Obchodní a živnostenské komory v Brně. Přátelství $\mathrm{s}$ Vaňkem nasměřovalo její tvorbu k praktičnosti, účelnosti a jednoduchosti. Božena navrhovala oděvy pro studentky či pracující ženy.

${ }^{1}$ Maria SZADKOWSKA (ed.), Božena Rothmayerová Horneková a Alice Masaryková. Svěřenkyně a mentor (1926-1939), Praha 2019, s. 32. 
V roce 1931 sestavila Božena garderobu i pro Alici Masarykovou, a to s ohledem na její společenské povinnosti. Zda byly návrhy realizovány, se bohužel nedozvídáme. Velmi zajímavé by bylo zamyšlení nad proměnou Alicina vztahu k vlastnímu šatníku. V Alicině pozůstalosti se dochovala dokumentace jejích pracovně/soukromých cest po vzniku republiky do Pař́že a hlavně Londýna, stejně jako řada účtů. V letech 1919 a 1920 tak lze dobře rekonstruovat, co nakupovala. Vedle kancelářských potřeb pro Československý červený kříž (ČSČK) to byly hlavně knihy a móda. Deset let před tím, než racionalizovala svůj šatník (nebo to minimálně měla v plánu) za pomoci textilní výtvarnice, utrácela za látky, šaty, doplňky a švadleny značně vysoké sumy. Důvodem zřejmě byla skutečnost, že zastupovala nemocnou a posléze zemřelou matku v roli první dámy a s tím souvisela nutnost reprezentace. Na desítkách fotografií z oficiálního hradního života je Alice zachycena v módních oděvech, nepochybně šitých na míru. Dle účtů byla zákaznicí těch nejznámějších módních závodů - Hanny Podolské a Oldřicha Rosenbauma. Při důkladnějším průzkumu vizuálních pramenů by snad bylo možné vysledovat, zda se spolupráce s Boženou nějak promítla $\mathrm{v}$ jejím reálném šatníku. To by jistě bylo $\mathrm{k}$ danému tématu velmi př́nosné.

Po příchodu na pražský Školský ústav pro domácký průmysl v roce 1934 se Božena přiklonila k tvorbě interiérového textilu a krajky, především návrhům prostírek. Tvarosloví jejích návrhů bylo ovlivněno osobnostmi krajkářek Emilie Paličkové a Marie Sedláčkové Serbouskové, které stály u zrodu české moderní krajky a které zde učily. Tehdy si Alice u Boženy objednala textilie pro svůj letní dům ve slovenské Bystričce či stolní textil a dečky pro londýnskou rezidenci svého bratra Jana Masaryka.

Boženu pověřila i úkolem vytvořit nový stejnokroj Československého červeného kříže, otázkou však je, zda byl realizován. Mužský, až uniformní ráz oděvu byl Boženě podle fotografií očividně blízký. Stejně jako jiné moderní ženy se nechala ostř́hat na mikádo, nosila pánský styl oděvu - košili s jednoduchou tmavou sukní, vestu, případně vázanku, jednoduché tmavé šaty se světlými doplňky - límcem, vsadkou, vázačkou - přesně jak o tom psala v módních hlídkách její kolegyně z projektu Civilisovaná žena Milena Jesenská. Tento styl zrrejmě inspiroval i Alici, která pod vlivem Boženy a jejích návrhů oděvů pro studentky zařadila do svého šatníku vázanku, tedy čistě pánský doplněk. Stalo se tak však až v době, kdy vázanka v dámském šatníku zcela zdomácněla a nebyla již jako ve 20. letech vnímána jako převzatý pánský prvek. Korespondence a seznamy návrhů modelů pro Alici jsou zřejmě jediným pramenem $\mathrm{k}$ této Boženině tvorbě. Je tedy otázkou, v jakém rozsahu byly realizovány, a zda vůbec našly své místo v reálném šatníku Alice Masarykové či žen v ČSČK.

Obliba edic korespondencí osobností z nejrůznějších oblastí veřejného života u čtenářů dlouhodobě stoupá. Právě určitá autentičnost a zároveň subjektivita je činí tak zajímavými. Lze je tak zařadit blízko memoárům či literatuře faktu. Není to tedy pouhý historický pramen, obzvláště měl-li pisatel blízko k literárnímu a uměleckému světu. Zásadní roli hraje interpretace korespondence jako pramene a její zasazení do širších souvislostí pisatele i jeho doby. S tím se autorka vyrovnává velmi úspěšně.

Szadkowska podnikla rozsáhlou heuristiku v řadě institucí. Vedle domovského Muzea hlavního města Prahy² je nejvíce předmětů vztahujících se k osobnosti Boženy Rothmayerové Hornekové uloženo v pražském Uměleckoprůmyslovém museu. $\mathrm{O}$ zhodnocení těchto předmětů požádala kurátorku Markétu Vinglerovou. Ta zpracovala akviziční historii předmětů a pokusila se je úspěšně zasadit do kontextu soudobé umělecké tvorby i Boženina života. Jasně strukturalizovala a vyjmenovala, co sbírky obsahují. Přehledná je i katalogová část $\mathrm{s}$ fotodokumentací předmětů a obsažnými popiskami. Jedinou drobnou nepřesností tak zůstává popiska pláště ze zlatavého hedvábí, který je v textu datován po roce 1925 a v popisce 1945-1957. Škoda jen, že prredměty Uměleckoprůmyslového musea nedostaly v obrazové př́loze podobně rozsáhlý prostor jako předměty Muzea hlavního města Prahy.

Stejné přehledné zhodnocení, jakého se dostalo sbírce Uměleckoprůmyslového musea, bohužel absentuje u toho nejdůležitějšího pramene, tj. u samotné písemné pozůstalosti manželů Rothmayerových uložené v Muzeu hlavního města Prahy. V úvodu publikace je uvedeno, že v pozůstalosti je uloženo více než 80 dopisů mezi Alicí Masarykovou a Boženou Rothmayerovou Hornekovou z let 1926-1939. V edici jsou však zahrnuty i dopisy několika dalších osob, např. Otto Rothmayera, Kýry Klinderové, hradního knihovníka Oskara Odstrčila, Aloise Pižla z Ministerstva školství a národní osvěty či sochaře Stanislava Suchardy. Přesnější charakterizování těchto dokumentů by jistě bylo ku prospěchu věci. Není totiž zcela pochopitelné, zda jsou v edici otištěny všechny dopisy či jen výběr. Součástí edice jsou i dopisy Boženy Alici, zřejmě jejich koncepty či průklepy. Logicky se tak nabízí otázka, zda nejsou v pozůstalosti Alice Masarykové dochovány další Boženiny dopisy. Autorka si tuto otázku jistě položila, nebot' fond Alice Masarykové, který je uložen v Archivu Masarykova ústavu, uvádí v seznamu pramenů. Nepochybně si také odpověděla, že písemnosti Alice Masarykové se dochovaly jen v torzovité podobě a z velké části souvisí s její činností v Československém červeném kříži. Jediný zde dochovaný dopis označený jménem Boženy Hornekové je ve skutečnosti koncept Alice Boženě. ${ }^{3}$ Ten je $\mathrm{v}$ edici sice otištěn $\mathrm{z}$ originálu uloženého v Muzeu hlavního města Prahy, zmínka o neexistenci druhé části korespondence zde ovšem schází. I negativní zjištění může být důležité.

Edice korespondence zabírá v knize 36 stran (189-225). Předchází jí reprodukce dopisů, označené jako výběr (téměr̆ třetina editovaných), avšak s rozsahem 75 tiskových stran (112-187) značně převyšující rozsah samotné edice. Další dopisy jsou navíc součástí obrazové př́lohy kapitol úvodní studie. Výběr reprodukcí není uspořádán chronologicky a ani jiná logika tohoto výběru bohužel není zcela zřejmá. Pro účel této publikace by bylo vhodné výběr přizpůsobit snaze otisknout především dopisy vykazující specifické rysy Aliciny epistolografie, listy doplněné kresbami a návrhy, zajímavé hlavičkové papíry apod.

\footnotetext{
2 Muzeum hlavního města Prahy, Sbírka Müllerova vila, fond Božena Rothmayerová.

3 Archiv Masarykova ústavu, fond Alice Garrigue Masaryková, inv. č. 19.
} 
Rozborem korespondence Marie Szadkowska došla k závěru, že vztah Boženy s Alicí Masarykovou zásadně formoval její umělecké zrání. Jejich poměr pak charakterizovala jako vztah mentora a svěřenkyně. Většinu životních milníků v tvorbě Boženy Rothmayerové Hornekové dává autorka do souvislosti se vztahem s Alicí Masarykovou. Označení Alice jako mentora není v textu pojímáno s negativní konotací významu tohoto slova. Alice byla Boženinou pedagožkou a minimálně v době studia, vzhledem $\mathrm{k}$ Boženině špatnému prospěchu, asi i karatelkou, avšak toto období nelze označit jako formující. Od druhé poloviny 20. let, kdy obě ženy znovu navázaly kontakty, byla Alice spíše výjimečnou zákaznicí zadávající Boženě práci.

Velmi kladně je třeba hodnotit velkorysou obrazovou výbavu knihy, která barvitě doplňuje text. Autorce se podařilo nashromáždit opravdu mimořádně rozsáhlý, komplexní a pestrý soubor fotografií, které dokumentují jak život Boženy Rothmayerové Hornekové, tak její tvorbu. Tematické uspořádání obrazové př́lohy je velmi přehledné a pomáhá čtenáři uvědomit si zásadní okruhy, kterým se Božena během své tvorby věnovala. Publikaci poněkud ubližuje již zmiňovaná nevyváženost grafického pojetí částí zpracovaných Muzeem hlavního města a Prahy a Uměleckoprůmyslovým museem i rozsah a úroveň popisek. Fotografie předmětů ze sbírek Uměleckoprůmyslového musea by si zasloužily celostránkový prostor a obrazová př́loha s předměty ze sbírek Muzea hlavního města Prahy obsažnější popisky. Praktická výtka směřuje $\mathrm{k}$ umístění popisek velkých fotografií z úvodu kapitol, nebot' ty jsou zařazeny na samotném závěru kapitoly, kde by je čtenář sotva hledal.
Psát recenzi na edici korespondence Alice Masarykové s Boženou Rothmayerovou Hornekovou bylo velmi lákavé. Dvě výjimečné ženy, zajímavá témata v korespondenci, kvalitní ediční práce, krásná publikace. Naznačené slibuje recenzentovi snadnou práci. To vše jsem také v knize nalezla, ale zároveň mi její přečtení otevřelo řadu dalších otázek. Odpovědi na tyto otázky možná ani nalézt nelze, ale je škoda, že se je autorka nepokusila alespoň pojmenovat.

Co je na celém příběhu osobních písemností manželů Rothmayerových nejvíc zarážející, ale v tom nejlepším slova smyslu, je to, jak se dostaly do sbírek Muzea hlavního města Prahy. Syn manželů Jan, mimochodem v knize je zachycen jako dětský model modelů své matky, je totiž věnoval v roce 2010 původně do sbírek Uměleckoprůmyslového musea v Praze. Díky iniciativě kurátora sbírky fotografie Jana Mlčocha byly následně předány do Muzea hlavního města Prahy, které spravuje Rothmayerovu vilu. To je obdivuhodné počínání muzejníka - „vzdát se“ sbírkového předmětu ve prospěch jiné instituce, aby tak byla sbírka zkompletována.

Kniha Marie Szadkowské představuje chvályhodný počin seznámení odborné veřejnosti s osobností nepříliš známé výtvarnice. Tato skromná tichá žena byla obdařena mimořádným talentem, jedinečným vnímáním estetična a pečlivostí. Na formování těchto vlastností se podílel výraznou měrou vliv Alice Masarykové. Za toto nové zjištění vděčíme Marii Szadkowské. Čtenáři se tak dostává do rukou kniha, která nepochybně obohatí o další rozměr naše znalosti o vývoji dějin textilu, módy a designu nejen meziválečného Československa. 